\title{
Influence of Participation Budgeting to Performance of Local Government
}

\author{
Nesti Hapsari, Dian Hakip Nurdiansyah \\ Faculty Economic and Busineess \\ Universitas Singaperbangsa Karawang \\ nestihapsarimsi@yahoo.co.id
}

\begin{abstract}
Participation budgeting is the important issues to performance of local government. The purpose of this studies to know the influence of budget participation towards performance of local government. This research included some organizational contingency variable such as: budget emphasis, budget goal clarity, organizational culture and decentralization system these parameters can act as moderating factors that can strengthen or weaken the bond between budget participation and performance of local government. Sample of this research are 47 SKPD in Karawang District, with structural functionary who participate on forming budget. This research uses primary data derived from questionnaires. Then, data was processed and analyzed using SPSS 17 for windows program. The results show that budget participation has a significant positive effect toward performance of local government. Moreover, organizational culture and decentralization system has a significant positive effect as moderating variable of budget participation and performance of local government. Whereas budget emphasis and budget goal clarity can't moderate the bond between budget participation and performance of local government.
\end{abstract}

\section{Keywords - Influence, budget, emphasis business}

\section{INTRODUCTION}

The process of Regional Budgeting is a part of state's financial system regulated in Law No. 17 of 2003. Regional Budget (APBD) is the annual financial plan of local government approved by the Regional People's Representative Assembly (DPRD). The budgeting process is fully the responsibility of local government as stipulated in Government Regulation No. 58 of 2005 on Regional Financial Management.

Participation in the context of budgeting is the process by which individual performance is evaluated and awarded based on the achievement of the budget, get involved and has an influence in the budgeting goal [1]. In other words, budgeting is carried out jointly by top level officials to lower level officials (bottom-up). Research on the budget partitcipation to managerial performance is debatable [2], in the research before found that participation in budgeting has significant and positive effect on managerial performance [3].

In Indonesia, the implementation of performance-based budgeting is latterly implemented from the fiscal year of 2005 with reference to Law No. 17 of 2003 on State Finance and Law No. 25 of 2004 on National Development Planning System. However, the practice of this system seems not yet able to optimize the performance of government officials.
Based on data of FITRA on the last 5 years Trend Expenditure, employee expenditure has a tendency to continue to increase, while the employee duties (Expenditure on Goods and Services) do not show a significant increase.

In Karawang itself as one district which has implemented the Decree of the Minister of Home Affairs No. 29 of 2002, ie performance-based budgeting, according to the Regent Regulation No. 113 of 2010 on Regional Budget Elaboration of Karawang Regency in 2013, for the 2013 Regional Budget, the government has allocated direct expenditures to the construction of only $35.18 \%$ or Rp 538.835 billion out of total expenditure of $\mathrm{Rp}$ 1,531 trillion. While indirect expenditures such as the cost of employee salaries, official travel, allowance, operating expense and others reach $64.8 \%$ or $\mathrm{Rp} 993.186$ billion. It is similar to 2014 for the 2014 Regional Budget, the direct expenditures to the construction are only $44 \%$ or Rp 700 billion, while indirect expenditures such as the cost of employee salaries, official travel, allowance, operating expense and others reach Rp 900 billion, or $56 \%$.

The measurement results of government performance in Government Performance Accountability Report (LAKIP) of Karawang regency in 2014, record that the realization of the performance of the funds to direct expenditures to fund the implementation of local government affairs in Karawang regency reaches only $94.86 \%$ of the budget ceiling. From these facts, it appears that the performance of local government is still less than optimal. The increased budget in each year is not balanced by the performance of local government officials. The budget should be optimized to finance the activities aimed at meeting the needs of local communities. Optimization of budget participation in which the aspiration of the community and local technical officials which have contributed in budgeting is possible to improve the performance of government.

These reasons are eventually encouraging the researchers to conduct further research on the influence of budget participation on the performance of local government officials by including contextual organizational contingency variables in accordance to the suggestion from Brownell [3] such as budget emphasis, budget goal clarity, organizational culture and decentralization systems. The aim of the addition of contextual organizational contingency variables in this study is to obtain a thorough conclusion, whether organizational practices in Karawang regency have been able to maximize participation in budgeting, which is expected to improve the managerial 
performance of Local Government itself. The population in this study is the office/agency members of the Rregional Work Units (SKPD) of Karawang Local Government.

\section{LITERATURE REVIEW AND HYPOTHESIS}

Definition of the budget according to Jones and Pineberry in the literature of "Financial Management" [4] is a government work which is manifested in the form of money (rupiah) during a certain period (1 year). The budget is used as a tool to determine the amount of expenditures, aids decisionmaking and development planning, authorizes the future expenditure, the source of the development of standard measures for evaluating the performance and as a means to motivate employees and coordination instruments for all the activities of various units.

According in the "Public Sector Accounting", public sector budgeting is associated with the process of determining the number of funds allocated to each program and activity in monetary units[5].

Government Regulation No. 58 of 2005 and the Decree of Minister of Home Affairs No. 13 of 2006 article 93, explain that the main element of performance-based budget is as follows:

\section{A. Performance indicators}

Performance indicator is a measure of success to be achieved from the program and planned activities. Each work unit area performs the activities and expenditures, the performance in question will illustrate the level of achievement of the implementation of an activity, program, and policy in realizing the goals, mission, and vision of the work unit. Performance achievement is stated in Government Performance Accountability Report (LAKIP) as stipulated in Government Regulation No. 13 of 2006.

\section{B. The achievement or performance targets}

The achievement or performance target is a measure of performance achivement to be achieved in the form of quality, quantity, efficiency and effectiveness in the implementation of all programs and activities. In line with the implementation of performance-based budget, the establishment of local budget should be based on the performance targets that have been set.

\section{Standard Spending Assessment}

Standard spending assessment is reasonableness assessment on the workload and costs used to carry out an activity. Assessment of reasonableness is based on the proportionality between the allocation of costs and performance achievement which are expected to achieve a goal and synchronized with the duties and functions of units within the public service.

\section{Standard unit price / standard cost}

The standard unit price is the unit price of each unit of goods/services applicable in an area defined by decision of regional heads. This standard serves as a means of controlling the allocation of funds, so that it avoids the mark-up in budgeting and can be used as a simple indicator in assessing the efficiency and the effectiveness of budget.

\section{E. Minimum Service Standards}

Minimum service standard is a benchmark in determining the performance achievements of the type and quality of basic services that are local obligatory. Performance benchmark is a measure of the success achieved in each of the local work unit, adjusted to the needs of the public aspirations as outlined in the performance indicators set out in local regulations.

The implementation of performance-based budgeting changes the paradigm of performance assessment of agency/unit, which in the past is based on the amount of funds absorbed from a program/activity, the assessment based on the achievement of performance as measured by substantive indicators produced by a program/activity carried out by Value for Money that is efficient, effective and economical, and in line with the policy and mission and vision of the organization. Value For Money is at the core of performance measurement in government organizations.

The definition of participation in the literature of "Behavioral Accounting" is the involvement of middle and lower level managers (operating managers) in decision-making that leads to the determination of the operational objectives and determination of performance target. In this case, the budget is prepared using bottom-up system by fully involving subordinates accountable for meeting targets set in the budget [6].

Budget participation in local government itself occurs when between the executive, the legislature and the public to cooperate in budgeting. The process of local budget with performance approach in Decree of Minister of Home Affairs contains Guidelines for Regional Budgeting implemented by executive budget team and regional organization unit jointly. The budget is made by the regional head through the proposal of work units delivered to the regional head and proposed to the regional head, which jointy with the Regional People's Representative Assembly set the budget in accordance with applicable regional regulations.

Budget emphasis is the reward system or performance appraisal for subordinates based on the achievement of budget targets, or if the leadership perceives that the performance and reward are assessed based on the budget targets achieved.

Apart from the impact of budget emphasis on subordinate behavioral change on the performance, with the presence of budget emphasis system, subordinates who felt that their performance will be assessed based on the budget achievement and performance targets will be motivated to participate in the budgeting, because they then can determine the target within its capabilities. Thus, budget emphasis is thought to have an influence on the budget participation.

There are two characteristics of budgeting system, namely participation in budgeting and budget goal clarity. Furthermore, described the budget goal clarity as the extent of budget goal is set clearly and specifically with the aim that the budget can be understood by the person responsible for the achievement of the budget target [7]. 
In the context of local government, budget goal is included in the Regional Medium-Term Development Plan (RPJMD) and the Regional Work Plan (RKPD). The goal is then used as guidelines in Budget Plan SKPD (RKA SKPD) which is a form of participation of each unit in budgeting. In RKA SKPD, each SKPD already contains performance indicators that will be achieved for each program and activities to be undertaken including input, output and outcome of each program. RKA SKPD will be used in carrying out their duties.

Participation refers to the involvement of middle and lower level managers in decision-making that leads to the determination of the operational objectives and target performance. Participation of managers in budgeting will be made to understand the objectives to be achieved by the budget, and how to achieve using the available resources (input) organization. To determine budget target accurately, the employees need a budget goal clarity. Thus, participation through clear budget goal is expected to improve the performance of local governments [8].

Organizational Culture defined organizational culture as a set of assumptions, beliefs, values and perceptions owned by the members of the group and an organization that form and influence the attitudes and behavior of the group concerned. [9]

Employee-oriented culture illustrates the organization's internal environment where the organizations pay more attention to the interests of the workers and not only to the work-related interests such as employee welfare, but also the personal interests of workers. In addition, workers are also involved in the important decisions of the organization. Meanwhile, job-oriented culture assumes that the employee must prioritize work above personal interests. Organizations only care about the employee's job, not to the fate of employees.

The definition is revealed, namely the decentralization as a system that encourages a variety of managers in a hierarchy to think and act independently while at the same time as a part of a team. The relationship between the centralization with the budget system design, found that the budget system design will be effective in a decentralization company. Decentralization allows organizations to respond to a problem more quickly and effectively, because the subordinates who are closest to the issues occured, so that subordinates have the best information and the expected performance will increase. Thus, the budget system in decentralization organizational system will affect managerial performance.

\section{Methodology ReSEARCH}

The population in this study is the structural officials involved in the budgeting practices in Karawang regency. Total population of SKPD in Karawang involved in the budgeting consists of 2 Secretariat namely the Regional Secretariats and the Secretariats of Parliament, 13 Regional Offices, 12 Regional Technical Institutes, 27 Sub-Districts, 30 Villages and 1 Other Agency namely Civil Service Police Unit.

Data collection method is obtained through literature study by using and applying the theories of reference books, research journals, magazines, and other literature relating to research.
Measurement instrument used is Likert scale of 1 to 5 point. Scale 1 shows a very bad performance while the scale 5 shows the very good local government performance.

In validating the hypotheses that have been formulated and submitted, the analytical techniques used is moderation regression analysis and in its calculations using analytical tools of SPSS version 18.0. Before the questionnaire is used in the study, it should be first tested for validity and reliability, and then test the classical assumption. The validity type used in the validity testt is construct validity, this type correlates the item value with the total value. If the correlation coefficient is significant (less than $\alpha=5 \%$ ), the instrument used is valid. [10]

The instruments are said to be reliable if there are similarities of data in different times, the measuring instrument is said to be reliable if the value of Cronbach Alpha is > 0.60. In Classical Assumption Test, there are several assumptions that must be met in the preparation of a linear regression model so that that results are not biased. Classical Assumption Test used in this study are multicolinearity test, heterocedastity test and normality test [11].

Test for normality in this study uses a non-parametric statistical test of Kolmogorov-Smirnov that is normality test using the cumulative distribution function. The criterion used in this case is to compare p-value obtained with a predetermined significance level of $5 \%$. If the p-value is $>$ the significant value, then data distribution is normal [12].

Data analysis techniques used in this study is the Simple Regression Data Analysis Techniques and Moderation. This analysis technique is used to determine the influence of budget participation on the performance of local government officials with budget emphasis, budget goal clarity, organizational culture and decentralization system as moderating variable.

\section{RESULTS AND DISCUSSION}

The study was conducted on the personnels in the Regional Work Unit (SKPD) of Karawang Regency who participated in the budgeting on education, especially Secretary/equivalent to SKPD Secretary, Head of Division/equivalent to Head of Division, and Head of Section/equivalent to Head of Section in which the three positions are involved directly in the preparation of RKA-SKPD. Questionnaires were distributed to 47 (fifty) SKPDs in which each selected three personnel as samples with structural role in the budgeting on education as the respondents in this study.

Based on questionnaire distribution list above, it can be concluded that as many as 133 questionnaires were distributed by the proportion of 38 questionnaires $(28.5 \%)$ for the Offices, 28 questionnaires $(21.05 \%)$ for the Regional Technical Institutes, 28 questionnaires $(21.05 \%)$ for the Districts, 28 questionnaires $(21.05 \%)$ for the Villages, 33 questionnaires (24.8\%), for the Regional Secretariats and three questionnaires $(2.26 \%)$ for Other Agencies. However, there are as many as 9 package questionnaires which are not returned from the Offices, seven packages from the Regional Technical Institutea, 5 packages from the Districts, four packages from the Villages, and three package questionnaires were not returned due to the busyness of the respondents, so that the 
questionnaires which can be processed are as many as 105 questionnaires with a response rate of 79 .

From the results of Validity Test, validity testing used in this study is to correlate each question in each variable with a total score using the correlation formula of Product Moment with SPSS 17.0. It is known that Corrected Item-Total Correlation $\left(\mathrm{r}_{\text {count }}\right)$ correlates with Product Moment in each statement item to the budget participation variable $\left(\mathrm{X}_{1}\right)$, budget emphasis $\left(\mathrm{X}_{2}\right)$, budget goal clarity $\left(\mathrm{X}_{3}\right)$, organizational culture $\left(\mathrm{X}_{4}\right)$, decentralization system $\left(\mathrm{X}_{5}\right)$, and the local government performance $(\mathrm{Y})$, is greater than the critical value $\left(\mathrm{r}_{\text {table }}\right)$ of 0,2188 at the significance level of $95 \%(\alpha=0.05)$. Thus, the entire item statements are declared valid, so that it can be used as a means of data collection.

Based on the results of Reliability Test, reliability testing is done by using Cronbach Alpha, where a research instrument is declared reliable if the alpha value is $>0.60$. The calculation of the value of the reliability coefficient for the instruments used in this study uses SPSS 17.0 For Windows. The results are obtained from testing the reliability of research instrument, because the value of Cronbach Alpha coefficients is $>0.60$, it can be concluded that the entire research instruments are deemed reliable.

The results of Descriptive Statistics Analysis are based on the descriptive table above, it can be seen that for a budget participation variable $\left(\mathrm{X}_{1}\right)$, the lowest score is 10 and the highest score is 30 , so the average score obtained (mean) is 21.8381 which when divided by 6 the questions, it is obtained that the average of respondents' answers are on scale of 4 (agree). In conclusion, budget participation is at the level of the average response of agree indicating that the level of participation of employees in the budgeting at the Local Government of Karawang Regency is quite high, because it is based on indicators of questions in the questionnaire, the more answers exceed the scale 3 (neutral), the higher the respondents' opinion in relation to its participation in the budgeting.

Variable of budget emphasis $\left(\mathrm{X}_{2}\right)$ shows the lowest score is 10 and the highest score is 30 , so the average score obtained (mean) is 21.6000 which when divided by 6 the questions, it is obtained that the average of respondents' answers are on scale of 4 (agree). In conclusion, budget emphasis is at the level of the average response of agree indicating that respondents feel the emphasis on budget in Local Government of Karawang Regency is quite high, because it is based on indicators of questions in the questionnaire, the more answers exceed the scale 3 (neutral), the higher the respondents' opinion in relation to its emphasis in the budgeting.

Variable of budget goal clarity $\left(\mathrm{X}_{3}\right)$ shows the lowest score is 12 and the highest score is 35 , so the average score obtained (mean) is 28.2571 which when divided by 7 questions, it is obtained that the average of respondents' answers are on scale of 4 (agree). In conclusion, the budget goal clarity is at the level of the average response of agree indicating that the level of budget goal clarity formed in Local Government of Karawang Regency is high, because it is based on indicators of questions in the questionnaire, the more answers exceed the scale 3 (neutral), the higher the respondents' opinion in relation to its emphasis in the budgeting.

Variable of organizational culture $\left(\mathrm{X}_{4}\right)$ shows the lowest score is 14 and the highest score is 35 , so the average score obtained (mean) is 24.2952 which when divided by 7 questions, it is obtained that the average of respondents' answers are on scale of 4 (agree). In conclusion, the organizational culture is pertained as high scale/score, meaning that the organizational culture in the Karawang regency government tends to be employee- oriented.

Variable of decentralization system $\left(\mathrm{X}_{5}\right)$ shows the lowest score is 4 and the highest score is 20 , so the average score obtained (mean) is 11.0381 which when divided by 4 questions, it is obtained that the average of respondents' answers are on scale of 3 (neutral). In conclusion, the respondents' opinion regarding the decentralization system in the organization in Local Government of Karawang Regency is classified as neutral.

Variable of local government performance (Y) shows the the lowest score is 13 and the highest score is 33 , so the average score obtained (mean) is 26.528 which when divided by 7 questions, it is obtained that the average of respondents' answers are on scale of 4 (agree). In conclusion, the local government performance is at the level of the average response of agree indicating that the performance of Local Government in Karawang Regency is high, because it is based on indicators of questions in the questionnaire, the more answers exceed the scale 3 (neutral), the higher the respondents' opinion in relation to its emphasis in the budgeting.

\section{A. The Results of Classical Assumption Test}

\section{1) Normality Test}

Normality test aims to test whether the confounding or residual variable regression model has a normal distribution or not. One way to test normality is using a Sample Kolmogorov Test against on standard residual value of regression equation results. If the One Sample Kolmogorov-Smirnov Test is greater than significance level used $(\alpha=0.05)$, the data distribution is normal and vice versa.

Based on the table on the results of normality test using SPSS 17.0 For Windows found the value KolmogorovSmirnov by of 1.016 with asymp.Sig. (2-tailed) of $0.253>\alpha$ $(0.05)$, so it can be concluded that all the data are normally distributed.

\section{2) Heterocedastity test}

Heterocedastity symptoms appear when confounding variable of each observation is no longer consistent, but vary. To detect the presence or absence heterocedastity uses Glejser Test, if the probability of significance is above the level of confidence of $5 \%(0.05)$, it does not contain heterocedastity symptoms (Suliyanto, 2011). Based on the output SPSS 17.0 For Windows obtains the following results: 
TABLE I. AlPha VAlue (Sig.) Regression EQuATION Model

\begin{tabular}{l|c}
\hline \multicolumn{1}{c|}{ Variable } & \multicolumn{1}{c}{ Sig. } \\
\hline Budget Participation $\left(\mathrm{X}_{1}\right)$ & 0.697 \\
\hline Budget Emphasis $\left(\mathrm{X}_{2}\right)$ & 0.054 \\
\hline Budget Goal Clarity $\left(\mathrm{X}_{3}\right)$ & 0.187 \\
\hline Organizational Culture $\left(\mathrm{X}_{4}\right)$ & 0.838 \\
\hline Decentralization System $\left(\mathrm{X}_{5}\right)$ & 0.430 \\
\hline
\end{tabular}

The above results show that the regression model has no heterocedastity symptoms. It is due to the significance of budget participation variable $\left(\mathrm{X}_{1}\right)$, budget emphasis $\left(\mathrm{X}_{2}\right)$, budget goal clarity $\left(\mathrm{X}_{3}\right)$, organizational culture $\left(\mathrm{X}_{4}\right)$, to the value of the residuals of the regression equation is greater than its $\alpha$ of $0.05(\operatorname{sig} .>\alpha)$

\section{3) Multicolinearity Test}

Multicollinearity test is used to test whether the regression model found a correlation between the independent variables. In which if the regression model found a high correlation between the independent variables, regression model can be said to be good. How to detect multicollinearity can be done by looking at tolerance and variance inflation factor (VIF). Cut-off value used to indicate the presence of multicollinearity is tolerance of $>0.10$ or VIF of $<10$. Based on the results of multicollinearity test using SPSS 17.0 For Windows, tolerance and VIF values obtained are as follows:

TABLE II. VIF AND TOLERANCE VALUE OF REGRESSION EQUATION

\begin{tabular}{l|l|l}
\hline \multicolumn{1}{c|}{ Variable } & Tolerance & VIF \\
\hline Budget participation $\left(\mathrm{X}_{1}\right)$ & 0.233 & 4.298 \\
\hline Budget Emphasis $\left(\mathrm{X}_{2}\right)$ & 0.375 & 2.664 \\
\hline Budget goal clarity $\left(\mathrm{X}_{3}\right)$ & 0.665 & 1.503 \\
\hline Organizational Culture $\left(\mathrm{X}_{4}\right)$ & 0.153 & 6.529 \\
\hline Decentralization System $\left(\mathrm{X}_{5}\right) \quad$ & 0.807 & 1.240 \\
\hline \multicolumn{2}{|c}{${ }^{\text {b. }}$ Source : Primary Data Processing (Appendix 5) }
\end{tabular}

Based on the output, it can be concluded that the multiple linear regression model did not found multicolinearity for tolerance and VIF on each independent variable shows the number greater than 0.10 (tolerance $>0.10$ ) and less than 10 (VIF <10).

\section{a) Simple Linear Regression Analysis}

Testing the hypothesis 1, i.e the influence of budget participation $\left(\mathrm{X}_{1}\right)$ variable to the local government performance (Y) in this study uses simple linear regression analysis. Based on simple linear regression analysis with SPSS 17.0 For Windows, calculation results can be summarized as follows:

TABLE III. SUMMARY OF SIMPLE LINEAR REGRESSION ANALYSIS RESULTS

\begin{tabular}{|c|c|c|c|c|c|}
\hline & Model & $\begin{array}{c}\text { Regression } \\
\text { coefficient }\end{array}$ & $\begin{array}{c}\text { Adjusted } \\
\mathbf{R}^{2}\end{array}$ & $\mathbf{t}$ & $\begin{array}{c}\text { Sig } \\
\text {. }\end{array}$ \\
\hline A & Constant & 19.580 & & $\begin{array}{l}9.55 \\
0 \\
\end{array}$ & $\begin{array}{l}0.0 \\
00\end{array}$ \\
\hline $\mathrm{X}_{1}$ & $\begin{array}{l}\text { Budget } \\
\text { participation }\end{array}$ & 0.318 & 0.094 & $\begin{array}{l}3.42 \\
6\end{array}$ & $\begin{array}{l}0.0 \\
01\end{array}$ \\
\hline
\end{tabular}

Based on data in Table 14, several conclusions can be drawn. From the analysis above, it can be made simple linear regression equation as follows:

$$
\mathrm{Y}=19.580+0.318 \mathrm{X}+\mathrm{e}
$$

The regression equation indicates that:

- Constant value $(\alpha)$ is 19.580 meaning that if the budget participation is zero, then the value of the performance of local governments is amounted to 19.580 units.

- The value of the regression coefficients for the budget participation variable is 0.318 . This shows that budget participation variable has positive influence on the performance of local government. This means that if the other variable is in a state of constant, any increase in one budget participation variable will increase the performance of local governments amounted to 0.318 .

In addition, the value of Adjusted R Square is 0.094 or $9.4 \%$. This value indicates that the budget participation variable affects the performance of local governments by $9.4 \%$ while the remaining $90.6 \%$ is influenced by other unknown variables.

\section{b) Hypothesis Testing}

- T-test

T-test is used to determine the effect of independent variables on the dependent variables partially. This test uses SPSS 17.0 for Windows. Hypothesis 1 Testing, i.e. the influence of budget participation variable $(\mathrm{X} 1)$ to the local government performance (Y) uses a confidence level of $\alpha=$ 0.05 and a degree of freedom (nk), where $n=105$ and $\mathrm{k}=6$, unknown t-table value of \pm 2.275652 , the output is obtained as follows:

TABLE IV. The Result of T-Test of VARIABle $\mathrm{X}_{1}$ Against $\mathrm{Y}$

\begin{tabular}{l|c|c|c|l}
\hline \multicolumn{1}{c|}{ Variable } & $\mathbf{T}_{\text {count }}$ & $\mathbf{t}_{\text {table }}$ & Sig. & \multicolumn{1}{c}{ Decision } \\
\hline $\begin{array}{l}\text { Budget participation } \\
\left(\mathrm{X}_{1}\right)\end{array}$ & 3.426 & 2.275652 & 0.001 & $\begin{array}{l}\text { Ha } \\
\text { accepted }\end{array}$ \\
\hline \multicolumn{4}{|c}{ d. Source : Primary Data Processing }
\end{tabular}

Based on the results above, it is obtained $t_{\text {count }}$ to a variable budget participation amounting to 3.426 , so that $t_{\text {count }}$ is $>t_{\text {table }}$ and its significance value is less than 0.05 then $\mathrm{Ho}_{1}$ is rejected and $\mathrm{Ha}_{1}$ is accepted. It means that the variable of budget participation has positive and significant effect on the performance of local government. The higher the budget participation, the better the resulting performance.

TABLE V. TABLE 5. SUMMARY OF THE RESULT OF T-TEST WITH ABSOLUTE DIFFERENCE AGAINST Y

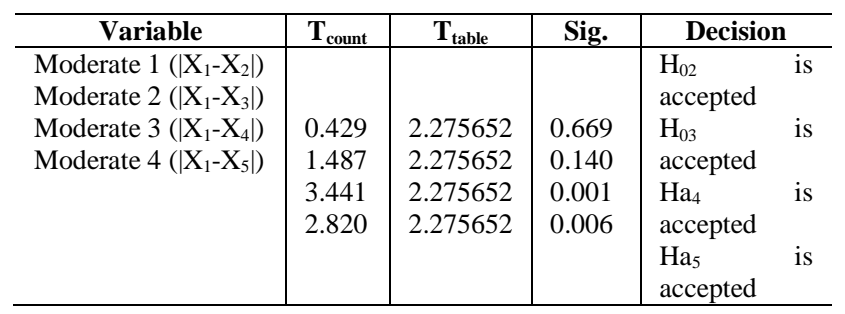


As for the next hypothesis, namely $\mathrm{H}_{2}, \mathrm{H}_{3}, \mathrm{H}_{4}$, and $\mathrm{H}_{5}$ in this study use multiple regression analysis in the form of Absolute Difference Value Test. The result can be seen in the summary of the t-test with a difference (Table V)

TABLE VI. THE RESUlt OF T-TEST With ABSOLUTE DifFERENCE OF VARIABLES OF BUDGET PARTICIPATION $\left(\mathrm{X}_{1}\right)$, BUDGET EMPHASIS $\left(\mathrm{X}_{2}\right)$ ON THE PERFORMANCE OF LOCAL GOVERNMENT (Y)

\begin{tabular}{|cl|l|l|l|l|}
\hline \multicolumn{1}{|c|}{ Model } & $\begin{array}{l}\text { Regression } \\
\text { coefficient }\end{array}$ & T & Sig. & AdjustedR2 \\
\hline 1 & (Constant) & 26.369 & 55.976 & 0.000 & 0.153 \\
& Zscore(X1) & 0.514 & 1.432 & 0.155 & \\
& Zscore(X2) & 1.068 & 2.987 & 0.004 & \\
Moderat1 & 0.429 & 0.429 & 0.669 & \\
\hline
\end{tabular}

Based on the results above, it can be made an equation regression as follows:

$$
\mathrm{Y}=26.369+0.514 \mathrm{X}_{1}+1.068 \mathrm{X}_{2}+0.210\left|\mathrm{X}_{1}-\mathrm{X}_{2}\right|
$$

From the equation, it can be explained as follows:

- Constant value is 26.369 which means when budget participation, budget emphasis and moderating variable has no change or constant, the performance of Local Government of Karawang Regency is 26.369 units.

- Regression coefficient is 0.514 , which means budget participation variable has a positive effect on the performance of local government, or functionally be declared if the budget participation increased by one unit, it will be able to improve the performance of the Government of Karawang Regency amounted to 0.514 units by assuming other variable is fixed (ceteris paribus).

- Regression coefficient is 1.068 , which means budget emphasis variable has a positive effect on the performance of local government, or functionally be declared if the budget emphasis has no increase or change, it will increase the performance of the Government of Karawang Regency amounted to 1,068 units by assuming other variable is fixed (ceteris paribus).

- Regression coefficient is 0.021, which means moderating variable $\left(\left|\mathrm{X}_{1}-\mathrm{X}_{2}\right|\right)$ has a positive effect on the performance of local government, or functionally be declared if a moderating variable increases by one unit, it will be able to improve the performance of local government amounted to 0,021 units by assuming other variable is fixed (ceteris paribus).

- The value of $t_{\text {count }}$ for moderating variable between budget participation with budget emphasis on the performance of local government is 0.429 , thus $t_{\text {count }}$ is $\leq t_{\text {table }}$ and its significance value is $0.669(>0.05)$ then $\mathrm{Ha}_{2}$ is rejected and $\mathrm{Ho}_{2}$ is accepted. Meaning that there are is significant effect between budget emphasis variable $\left(\mathrm{X}_{2}\right)$ in moderating variable in relation to budget participation $\left(\mathrm{X}_{1}\right)$ with local government performance variable (Y). These results show the budget emphasis is not able to moderate the level of budget participation of Karawang local government officials on the level of performance produced.
- The value of adjusted $\mathrm{R}_{2}$ is 0.153 , indicating that the compatibility between budget participation variable $\left(\mathrm{X}_{1}\right)$ with budget emphasis variable $\left(\mathrm{X}_{2}\right)$ is able to influence the performance of the local government (Y) by $15.3 \%$ while the remaining $84.7 \%$ is influenced by other unknown variables.

TABLE VII. The RESUlt OF T-TEST WITH ABSOLUTE DifFERENCE OF VARIABLES OF BUDGET PARTICIPATION $\left(\mathrm{X}_{1}\right)$, BUdGET GOAL CLARITY $\left(\mathrm{X}_{3}\right)$ ON THE PERFORMANCE OF LOCAL GOVERNMENT (Y)

\begin{tabular}{|c|l|l|l|l|}
\hline \multicolumn{1}{|c|}{ Model } & \multicolumn{1}{|c|}{$\begin{array}{c}\text { Regression } \\
\text { coefficient }\end{array}$} & $\mathbf{T}$ & Sig. & $\begin{array}{c}\text { Adjusted } \\
\boldsymbol{R}^{2}\end{array}$ \\
\hline 1 (Constant) & 26.055 & 60.034 & 0.000 & 0.170 \\
Zscore(X1) & 0.678 & 2.036 & 0.044 & \\
Zscore(X3) & 1.089 & 3.240 & 0.002 & \\
Moderat2 & 0.616 & 1.487 & 0.140 & \\
\hline
\end{tabular}

Based on the results above, it can be made an equation regression as follows:

$\mathrm{Y}=26.055+0.678 \mathrm{X}_{1}+1.089 \mathrm{X}_{3}+0.616\left(\left|\mathrm{X}_{1}-\mathrm{X}_{3}\right|\right)$

From the equation, it can be explained as follows:

- Constant value is 26.055 which means when budget participation, budget goal clarity and moderating variable has no change or constant, the performance of the Government of Karawang Regency is 26.055 units.

- Regression coefficient is 0.678 , which means budget participation variable has a positive effect on the performance of local government, or functionally be declared if the budget participation increased by one unit, it will be able to improve the performance of the Government of Karawang Regency amounted to 0.678 units by assuming other variable is fixed (ceteris paribus).

- Regression coefficient is 1.089 , which means budget goal clarity variable has a positive effect on the performance of local government, or functionally be declared if the budget goal clarity has no increased or change, it will increase the performance of the Government of Karawang Regency amounted to 1.089 units by assuming other variable is fixed (ceteris paribus).

- Regression coefficient is 0.616, which means moderating variable $\left(\left|\mathrm{X}_{1}-\mathrm{X}_{3}\right|\right)$ has a positive effect on the performance of local government, or functionally be declared if moderating variable increases by one unit, it will be able to improve the performance of local governments amounted to 0.616 units by assuming other variable is fixed (ceteris paribus).

- The value of $t_{\text {count }}$ for moderating variable between budget participation with the budget goal clarity on the performance of local governments is 1.487 , so that the value $t_{\text {hitung }}$ is $\leq t_{\text {tabel }}$ and its significance value is 0.140 (> 0.05) then $\mathrm{Ha}_{3}$ is rejected and $\mathrm{Ho}_{3}$ is accepted. Meaning that there is no significant effect between the 
budget goal clarity variable $\left(\mathrm{X}_{3}\right)$ in moderating variable in relation to budget participation $\left(\mathrm{X}_{1}\right)$ with local government performance variable $(\mathrm{Y})$. These results indicate that budget goal clarity is not able to moderate the level of budget participation of Karawang local government officials on the level of performance produced.

- The value of adjusted $\mathrm{R}_{2}$ is 0.170 indicating that the compatibility between budget participation variable $\left(\mathrm{X}_{1}\right)$ with budget goal clarity variable $\left(\mathrm{X}_{3}\right)$ is able to influence the performance of the local government (Y) by $17 \%$ while the remaining $83 \%$ is influenced by other unknown variables.

TABLE VIII. THE RESUlT OF T-TEST WITH ABSOLUTE DIFFERENCE OF VARIABLES OF BUDGET PARTICIPATION $\left(\mathrm{X}_{1}\right)$, ORGANIZATIONAL CULTURE (X4) ON THE PERFORMANCE OF LOCAL GOVERNMENT (Y)

\begin{tabular}{|c|c|c|c|c|c|}
\hline \multicolumn{2}{|r|}{ Model } & $\begin{array}{c}\text { Regression } \\
\text { coefficient }\end{array}$ & $\mathbf{t}$ & Sig. & $\begin{array}{c}\text { Adjusted } \\
R^{2}\end{array}$ \\
\hline \multirow[t]{4}{*}{1} & (Constant) & 26.121 & 72.293 & 0.000 & \multirow[t]{4}{*}{0.187} \\
\hline & Zscore (X1) & 1.144 & 4.248 & 0.000 & \\
\hline & Zscore $(\mathrm{X} 4)$ & 0.635 & 2.353 & 0.021 & \\
\hline & Moderat3 & 1.426 & 3.441 & 0.001 & \\
\hline
\end{tabular}

Based on the results above, it can be made an equation regression as follows:

$\mathrm{Y}=26.121+1.144 \mathrm{X}_{1}+0.635 \mathrm{X}_{4}+1.426\left(\left|\mathrm{X}_{1}-\mathrm{X}_{4}\right|\right)$

From the equation, it can be explained as follows:

- Constant value is 26.121, which means when budget participation, organizational culture and moderating variable has no change or constant, the performance of the Government of Karawang Regency is 26.121 units.

- Regression coefficient is 1.144 , which means budget participation variable has a positive effect on the performance of local government, or functionally be declared if the budget participation increased by one unit, it will be able to improve the performance of the Government of Karawang Regency amounted to 1,144 units by assuming other variable is fixed (ceteris paribus).

- Regression coefficient is 0.635 , which means the variable of organizational culture has a positive effect on the performance of local government, or functionally be declared if the organizational culture has no increase or change, it will increase the performance of the Government of Karawang Regency amounted to 0.635 units by assuming other variable is fixed (ceteris paribus).

- Regression coefficient is1.426, which means moderating variable $\left(\left|\mathrm{X}_{1}-\mathrm{X}_{4}\right|\right)$ has a positive effect on the performance of local government, or functionally be declared if a moderating variable increases by one unit, it will be able to improve the performance of local governments amounted to 1,426 units by assuming other variable is fixed (ceteris paribus).

- The value of $t_{\text {count }}$ for moderating variable between budget participation with the organizational culture to the local government performance is equal to 3.441 , so that $t_{\text {count }}$ is $>t_{\text {table }}$ and its significance value is 0.001 $(<0.05)$ then $\mathrm{Ha}_{4}$ is accepted and $\mathrm{Ho}_{4}$ is accepted. Meaning that, the level of correspondence between organizational culture $\left(\mathrm{X}_{4}\right)$ with the budget participation $\left(\mathrm{X}_{1}\right)$ can affect (increase/decrease) the performance of the Karawang local government (Y).

- The value of adjusted $\mathrm{R}_{2}$ is 0.187 indicating that the compatibility between budget participation variable $\left(\mathrm{X}_{1}\right)$ with the organizational culture variable $\left(\mathrm{X}_{4}\right)$ is able to influence the performance of the local government (Y) by $18.7 \%$ while the remaining $81.3 \%$ is influenced by other unknown variables.

TABLE IX. The RESUlt OF T-TEST WITH ABSOLUTE DifFERENCE OF VARIABLES OF BUDGET PARTICIPATION $\left(\mathrm{X}_{1}\right)$, DECENTRALIZATION SYSTEM $\left(\mathrm{X}_{5}\right)$ ON THE PERFORMANCE OF LOCAL GOVERNMENT (Y)

\begin{tabular}{|l|l|l|l|l|}
\hline \multicolumn{1}{|c|}{ Model } & $\begin{array}{c}\text { Regression } \\
\text { coefficient }\end{array}$ & $\mathbf{t}$ & Sig. & $\begin{array}{c}\text { Adjusted } \\
\boldsymbol{R}^{\mathbf{2}}\end{array}$ \\
\hline 1(Constant) & 25,818 & 43.605 & 0,000 & 0,253 \\
Zscore $(\mathrm{X} 1)$ & 1,621 & 5.455 & 0,000 & \\
Zscore $(\mathrm{X} 5)$ & 0,448 & 1.500 & 0,137 & \\
Moderat4 & 1,085 & 2.820 & 0,006 & \\
\hline
\end{tabular}

Based on the results above, it can be made an equation regression as follows:

$$
\mathrm{Y}=25.818+1.621 \mathrm{X}_{1}+0.448 \mathrm{X}_{5}+1.085\left(\left|\mathrm{X}_{1}-\mathrm{X}_{5}\right|\right)
$$

From the equation, it can be explained as follows:

- Constant value is 25.818 , which means when budget participation, decentralization system and moderating variable has no change or constant, then the performance of the Government of Karawang Regency is 25.818 units.

- Regression coefficient is 1.621 , which means budget participation variable has a positive effect on the performance of local government, or functionally be declared if the budget participation increases by one unit, it will be able to improve the performance of the Government of Karawang Regency amounted to 1.621 units by assuming another variable is fixed (ceteris paribus).

- Regression coefficient is 0.448, which means decentralization system variable has a positive effect on the performance of local government, or functionally be declared if decentralization system has no increased or 
change, it will increase the performance of the Government of Karawang Regency amounted to 0.448 units by assuming another variable is fixed (ceteris paribus).

- Regression coefficient is 1.085, which means moderating variable $\left(\left|\mathrm{X}_{1}-\mathrm{X}_{5}\right|\right)$ has a positive effect on the performance of local government, or functionally be declared if a moderating variable increases by one unit, it will be able to improve the performance of local governments amounted to 1.085 units by assuming another variable is fixed (ceteris paribus).

- The value of $t_{\text {count }}$ for moderating variable between budget participation with decentralization system of local government performance is equal to 2.820 , so that $\mathrm{t}_{\text {count }}$ is $>\mathrm{t}_{\text {table }}$ and its significance value is $0.006(<0.05)$ then $\mathrm{Ha}_{5}$ is accepted and $\mathrm{Ho}_{5}$ is rejected. Meaning that the level of correspondence between decentralization system $\left(\mathrm{X}_{5}\right)$ with budget participation $\left(\mathrm{X}_{1}\right)$ can affect (increase/decrease) the performance of the Karawang local government (Y). These results indicate the level of budget participation with decentralization system can increase/decrease the local government performance of Karawang regency.

- The value of adjusted $R_{2}$ is 0.253 indicating that the compatibility between budget participation variable $\left(\mathrm{X}_{1}\right)$ with decentralization system variable $\left(\mathrm{X}_{5}\right)$ is able to influence the performance of the local government (Y) of $25.3 \%$ while the remaining $74.7 \%$ is influenced by unknown other variables.

\section{CONCLUSION}

Based on the results and discussion on the influence of budget participation on the local government performance with budget emphasis, budget goal clarity, organizational culture and decentralization system as moderating variables can be concluded as follows:

Variable of budget participation is proved to have positive and significance effect on the local government performance of Karawang regency.

- Variable of budget emphasis is not able to moderate the effect of budget participation to the local government performance of Karawang regency.
- Variable of budget goal clarity is not able to moderate the effect of budget participation to the local government performance of Karawang regency.

- Variable of organizational culture is able to moderate the effect of budget participation to the local government performance of Karawang regency.

- Variable of decentralization system is able to moderate the effect of budget participation to the local government performance of Karawang regency.

\section{REFERENCES}

[1] Brownell, P. Participation in Budgeting, Locus of Control and Organizational Effectiveness. The Accounting Review. Vol. 56. 1982a. pp. 844-860.

[2] [2] Sulaksono, Tri. Budaya Organisasi dan Ketidakpastian Lingkungan sebagai Variabel Moderating dalam Hubungan antara Gaya Evaluasi Atasan terhadap Tekanan Kerja dan Kepuasan Kerja Bawahan (Studi pada PT. Bank Perkreditan Rakyat Wilayah Kantor BI Solo). Tesis. Program Studi Magister Akuntansi Program Pasca Sarjana Universitas Diponegoro. Semarang. 2005.

[3] Brownell, P. Participation in Budgeting, Locus of Control and Organizational Effectiveness. The Accounting Review. Vol. 56. 1982a. pp. 844-860.

[4] Halim, Abdul dan Theresia Damayanti. Pengelolaan Keuangan Daerah. Second Edition. UPP STIM YKPN. Yogyakarta. 2007.

[5] Mardiasmo. Akuntansi Sektor Publik. Penerbit Andi. Yogyakarta . 2002.

[6] Lubis, Arfan Ikhsan. Akuntansi Keperilakuan. Second Edition. Salemba Empat. Jakarta. 2010.

[7] Kenis, I. Effects of Budgetary Goal Characteristics on Managerial Attitudes and Performance. The Accounting Review. Vol. LIV. No. 4. October. pp. 707-721. 1979

[8] Lubis, Arfan Ikhsan. Akuntansi Keperilakuan. Second Edition. Salemba Empat. Jakarta. 2010.

[9] Sobirin, Ahmad. Budaya Organisasi. Edisi Kedua. UPP STIM YKPN. Yogyakarta. 2009.

[10] Ghozali, Imam. "Aplikasi Analisis Multivariate dengan program SPSS". Badan Penerbit Universitas Diponegoro. Semarang. 2005.

[11] Sugiyono. Metode Penelitian Bisnis (Pendekatan Kuantitatif, Kualitatif, dan R\&D). Bandung: Alfabeta. 2009.

[12] Ghozali, Imam. "Aplikasi Analisis Multivariate dengan program SPSS". Badan Penerbit Universitas Diponegoro. Semarang. 2005. 